\title{
War and Science. A Few Thoughts on the Research of the Institut für Deutsche Ostarbeit in Occupied Poland. A Case of Podhale Region
}

\begin{abstract}
The article refers to the research and activity of Nazi Institute für Deutsche Ostarbeit (IDO), which operated in occupied Poland between 1940-1944. Drawing on archival sources mainly on Diary of archeological research in Szaflary (1942), the author provides new and verifies existing information about research projects and expeditions carried by IDO in Poland, in this case by Section Vorgeschichte. This yet unknown Dictionary provides new insight not only into research procedures and excavations in Szaflary village but also into Germans ethnopolicy towards conquered nations (Polish Highlanders from Podhale region), as well as relations between German and Polish scientists. In that sense presented article contributes to the contemporary discussion about political involvement of German and academics in the Nazi regime, taking under consideration the relation between science, war, and power. The article is also questioning the problem of ethics, responsibility and political engagement of academics and the statues of data produced by IDO.
\end{abstract}

Keywords: science, war, domination, Nazi ethnopolicy, Górale, archeological research, Institut für Deutsche Ostarbeit, Section Vorgeschichte.

Even though over 70 years have passed since the end of World War II, the events that took place at that time are still being evoked, commemorated and re-interpreted, and often provoke extreme, emotional reactions in the public discourse. Many of the occupation events that occurred after the end of World War II have found a permanent place in the official history of Poland, and have become a testament of enslavement, martyrdom and heroism in a struggle against the German aggressor. Other events, especially those involving sensitive and often dramatic 
experiences, have been intentionally forgotten and excluded from the scope of the official history. Following the political transformation took place in Poland at the turn of the 1980s and the 1990s, these difficult stories and these politically inconvenient subjects have gradually been reintroduced into the social bloodstream, both in scientific publications (Szatkowski 2012; Maj 2015; Engelking, Grabowski 2018) and in other cultural texts; for example, an Andrzej Wajda film from 2007 entitled Katyn. ${ }^{1}$ Poorly-identified or previously unknown topics concerning various aspects of the reality of the occupation are continuing to emerge. Some of these events are still dormant in the memories of the last witnesses. Other events are hidden in the archives, waiting for their disclosure.

One of these sensitive topics, discussed reluctantly in the Polish historiography, is the involvement of Polish researchers with the Institut für Deutsche Ostarbeit (IDO, English: Institute for German Work in the East), also referred to as the Ost-Institut, which was established in Kraków, Poland in 1940 by the German occupying authorities. This is a topic that was avoided for many years, but returned to the public debate accompanied by huge media exposure in 2003, transforming into a contentious and emotional discussion. The discussion resulted from Aneta Rybicka's paper (2002) on the activities of the IDO, in which she considered the work of the researchers from Kraków in the German facility to be a collaboration. In refuting the accusations, the representatives of the Jagiellonian University (JU) emphasised that the participation of Polish researchers in the work of the IDO took the form of a resistance movement that was fully controlled by the Polish Underground State, which was provided with information about the research conducted in the Ost-Institut (Bałuk-Ulewiczowa 2004). The dispute that took place at the time resulted in a team of archivists being appointed to explain the involvement of the Kraków professors with the Nazi facility during the war (Maj, Trebunia-Staszel 2015). ${ }^{2}$ It also provoked a reflection on the dominant interpretations of the past found in the Polish historiography. Andrzej Chwalba, a participant in this discussion, concluded that, the right time to do our overdue history homework has came: "today, in a different atmosphere and a different historical time, we not only can, but even should address 'difficult topics"' (Chwalba 2003: 4).

1 As Enzo Traverso writes (2014: 18), this peculiar explosion of interest in memories, referred to as "memory turn" in European social and historical sciences, took place in the 1990s, although its origins date back to the 1980s. In Poland, the abovementioned term coincided with the political transformation and the democratisation of social relations. This is when the topics and events that were previously avoided, censored and suppressed in the Communist period began to be gradually disclosed.

2 The Division Archives of the Institute of National Remembrance in Kraków contain the documentation concerning the Poles employed in the IDO collected between 2003 and 2004 by a team of researchers appointed by the President of the Institute of National Remembrance, Leon Kieres. The Division Archives - the Commission for the Prosecution of Crimes against the Polish Nation. File: Thematic Query 3/33, Vols. 1-16. 
A few years after the abovementioned event, in 2008, the Archives of the Jagiellonian University obtained a vast collection of materials about occupied Poland from the Smithsonian Institution in Washington, created by the Sektion Rassen-und Volkstumsforschung (SRV, English: Section on Race and Ethnicity Research) that was operating as part of the IDO. The staff of the SRV had organised research expeditions between 1940 and 1944 to visit selected towns in the General Government $(\mathrm{GG})^{3}$ where they gathered an extensive collection of anthropological, sociological, medical and ethnographical data. After the collection of the SRV was brought to Poland, a group of ethnologists from the Institute of Ethnology and Cultural Anthropology of the Jagiellonian University began studying the documentation obtained from Washington, which allowed them to recreate the real scope of the activities of this section. In her 2004 book, Gretchen E. Schafft gave a brief earlier description of the abovementioned collection, and the ethnologists from Kraków presented a more thorough overview after in-depth research described in a joint volume entitled Antropologia i etnologia w czasie wojny. Działalność Sektion Rassen-und Volkstumsforschung Institut für Deutsche Ostarbeit, Krakau 1940-1944, w świetle nowych materiatów źródłowych (Maj 2015). The analysis conducted by the researchers showed that they were particularly interested in the Polish Górale (highlanders) inhabiting the Podhale region located in the Western Carpathians at the foothills of the Tatra Mountains. The factors that determined the exceptional status of this community, in light of the statements included in the plans and reports of the German researchers from the SRV (Fliethmann 1942; Plügel 1941a, 1941b), were the geographical location of the Carpathians, which was connected with the belief that the most archaic elements of human civilisation survived in the mountains, the Germanic influence in the towns with a confirmed mediaeval German colonisation, which affected the cultural characteristics of this group, and the scenic and touristic values of the region ${ }^{4}$ (Trebunia-Staszel 2017). It is worth noting here that the inhabitants of Podhale had also been noticed, appreciated and mythologised at an earlier time by Polish 19th-century ethnic studies scholars, authors and intellectuals, who underlined the "physical and intellectual beauty" of the region's inhabitants and, first and foremost, their sense of freedom, which was essential in the period of national enslavement ${ }^{5}$ (Trebunia-Staszel 2017). The zenith of the fas-

3 General Government (GG): an administrative unit established based on Hitler's decree of 12 October 1939, encompassing the part of the conquered Polish lands that was not directly incorporated into the Reich. The GG was supervised by the Governor General. Throughout the occupation, the office was held by a Nazi official, the lawyer Hans Michael Frank.

4 German dignitaries were especially fond of the Tatra town of Zakopane. After the invasion, the Germans created a restricted zone there as early as in February 1940, preparing the city to play the role of a health resort and a recreation centre for Wehrmacht soldiers and Nazi officials (Gąsiorowski 2010: 20-23).

5 As a result of the three partitions conducted by Austria, Prussia and Russia (1772, 1793, 1795), the Polish-Lithuanian Commonwealth stopped existing as an independent state. The Poles regained independence in 1918. 
cination with the Polish highlander culture took place at the turn of the 19th and 20th centuries, when the Podhale tradition was considered to represent a cache of "pre-Polish traits", and the highlanders were hailed as heroes of everyday life (Majda 1979: 114-115). This is when, in the spirit of a Neo-Romantic fascination about the region, a patriotic concept of the Polish highlander culture emerged, according to which the highlanders were the "pure" core of the Polish nation. Polish patriots first gave the Polish highlander culture its aura of uniqueness; while decades later, during World War II, the same culture became the subject of manipulation by the German invaders. The Nazi occupation authorities, in accordance with the "divide and conquer" principle, propagated the idea of a separate Górale nation, referred to as Goralenvolk, with an aim to weaken the solidarity of the Polish society that had been taking up arms against the invaders from the very first days of the occupation. Despite the increased propaganda and terror activities, the Nazi initiative ended in failure. Except for a small group of collaborators, the vast majority of the inhabitants of the Podhale villages (95\%) declared a Polish nationality when the identification documents were issued and chose Polish cards displaying the letter "P" (Pole) ${ }^{6}$ (Wnuk 1980: 37-39; Szatkowski 2012: 255-330). It should be emphasised here that, contrary to the common opinion, the SRV conducted research independently from the governmental Goralenvolk initiative. This ethno-political research, which served to the Nazi regime, encompassed not only the highlanders, but also the other communities inhabiting the area of the GG. Its purpose - as Nazi scientists claimed following the official German policy toward the occupied land - was to evaluate the racial structure of the conquered nations and to use the obtained data to ethnically reorganise the East under the Greater German Reich (Fliethmann 1942; Plügel 1941a).

In the SRV's research project in Podhale, special attention was paid to the Górale village of Szaflary, where in June and July 1942, a plan of anthropological, medical, sociological and ethnographical research was almost entirely carried out, and the collected data was supplemented with hundreds of photos. The detailed anthropometric measurements encompassed over 1000 inhabitants, which constituted almost the entire population of the village (Maj, Trebunia-Staszel 2015). Due to organisational problems, the researchers only did not manage to conduct psychological tests in Szaflary. As Doctor Elfriede Fliethmann, ${ }^{7}$ who was in charge of the SRV research in Szaflary, argued in her report, the village was chosen because of its German name and because it was a mediaeval settlement signifying

6 In the case of the entire Podhale, the rate was about $82 \%$. This resulted from the fact that more highlander Kennkarten "G" (Góral) were issued in the Podhale towns (Nowy Targ, Rabka and Zakopane), which according to the German interpretation, meant joining the Goralenvolk (Szatkowski 2012: 255-330).

7 Doctor Elfriede Fliethmann: an alumnus of the University of Vienna. She graduated in geography, history and anthropology and was involved politically. She taught racial politics to the National Socialist Women's League (Frauenschaft) (Michel 2000: 155). 
early German influences (1942: 273). In the project, a model of comprehensive research was applied based on the methodology developed by the "Vienna School" (Trebunia-Staszel 2017). According to Fliethmann, the aim of the project was to provide essential data for evaluating the local population in comparison to the German nation and to investigate the correlations of the racial composition, culture and influence of the environment with the relationships in the settlement, all in order to "create a foundation for transforming the inhabitants' living space in a manner appropriate to the biological and geographical conditions" (Fliethmann 1942: 272). As we can see, the research hypotheses and goals were strongly combined with political aims. The project in Szaflary was totally subjected to the Nazi policy toward this polish highlanders group. Its purpose was to evaluate Górale due to "their usefulness" to German nation, and potential Germanisation.

Concurrently with the research conducted by the SRV in Szaflary in 1942, two other Nazi sections began excavations. The German archaeologists were interested in a hill located on the outskirts of the village, called Skałka by the locals, which held the remains of a mediaeval wall and a pavilion called biaty domek (white house). The history of this building, dated to the period between the 13th and the 14th century, was to become another piece of evidence that confirmed the German character of Szaflary. The German archaeological research has been discussed in the Polish subject literature, but only in an incomplete and selective manner. Some of the data was mentioned, while other data was deliberately omitted (Wałowy 1960; Cabalska 1991; Kasperek 1990; Słuszkiewicz 1993; Kamiński 1993). ${ }^{8}$ However, the previously unknown archival materials discovered a few years ago have provided us with new data, which has considerably expanded our knowledge not only about the course of the excavation work itself, but also about the German interest in the highlander culture and the Polish-German relations, as well as the relationships in the Nazi institutions operating in occupied Poland. Therefore, it is worth revisiting this subject, as it addresses the more general issues being discussed presently in the studies on the IDO, including the political involvement of science, its connections with the authorities, violence and domination, and the cognitive status of the data produced for the use of the regime. Furthermore, it makes an important contribution to the discussion on the participation of the Polish scientists in Nazi research institutions, both in the context of

8 It is worth noting that in the Podhale regional historiography, the thread of the German excavations was also discussed superficially and in few publications. Thus, for instance, in a book entitled Podhale w latach wojny i okupacji niemieckiej 1939-1945 [Podhale during the War and German Occupation between 1939 and 1945] published in 1990, its author only noted that the research conducted on the castle hill by the IDO "was supposed to confirm the thesis promoted by the Germans that the monks who erected the castle came from Germany" (Kasperek 1990: 168). On the other hand, in joint publication entitled Szaflary. Wieś podhalańska (1993) [Szaflary. A Podhale Village], the two authors included a note in independent texts that in 1942, Professor Rudolf Jamka carried out archaeological work on the Skałka Hill (Słuszkiewicz 1993: 104; Kamiński 1993: 162). 
the selecting and silencing of data and in the simplified examination of particular facts from the period of occupation.

\section{The uniqueness of the Dziennik prac wykopaliskowych w Szaflarach}

The topic of the archaeological work in Szaflary appeared frequently in the discussions carried out between 2009 and $2012^{9}$ with the oldest inhabitants of Szaflary about the Nazi racial research. The interviewed persons usually provided only the laconic information that "the Germans dug on the Skałka Hill during the war". Only few mentions of this topic survived in the collection of the SRV provided by the Smithsonian Institution. More information was found in a 1943 report from the excavation work in Szaflary prepared by Elfriede M.L. John and published in the German journal "Deutsche Forschung im Osten" (1943: 47-53). In the Polish subject literature, Alicja Wałowy, an archaeologist from Kraków, was the first one to discuss the abovementioned research. In 1960, she published in "Materiały Archeologiczne" [Archaeological Materials] an article entitled Materialy z badań archeologicznych na średniowiecznym zameczku w Szaflarach, pow. Nowy Targ [Materials from the Archaeological Research in the Mediaeval Castle in Szaflary, Nowy Targ District], in which, based on the findings from 1942 stored in the Archaeological Museum in Kraków (AMK), she reconstructed the research that took place on the Skałka Hill, while at the same time attempting to analyse the obtained material (Wałowy 1960: 295-332). Characteristically, in her study, she entirely ignored the German context of the research, limiting herself only to the information that the work supervised by the Polish archaeologist Doctor Rudolf Jamka that was conducted in the castle began in 1942 (Wałowy 1960: 296). The matter was treated similarly by another archaeologist from Kraków, Maria Cabalska. In her article from 1993 about the prehistory of Podhale, she mentioned Wałowy's text only in her bibliography when discussing the findings excavated in 1942. She did not mention the German research, even though it was later found that she had participated in it herself (Cabalska 1991: 27-29). Today, with the added perspective of time and current knowledge, the author's self-censorship is easier to understand. The archaeological work on the castle hill in Szaflary was also mentioned by Jamka (1964), who supervised it, only intermittently and superficially. Furthermore, Stefan K. Kozłowski in his interesting book from 2012 entitled Archeologiczne królestwo Wernera Radiga w Generalnym Gubernatorstwie [Archaeological Kingdom of Werner Radig in the General Government], dedi-

9 The study was conducted by the author of the present text and by Doctor Małgorzata Maj as part of the research project carried out in the Institute of Ethnology and Cultural Anthropology of the Jagiellonian University. 
cated to the activities of the Sektion Vorgeschichte (Prehistoric Section) of the IDO, treated the topic only incidentally and mentioned it in the context of an embarrassing mistake, i.e. the discovery of an alleged "Germanic rotunda", which in the end turned out to be a modern lime kiln (Kozłowski 2012: 16, 41, 87). This may suggest that the author did not include the Dziennik prac wykopaliskowych w Szaflarach in his work [Journal of the Excavation Work in Szaflary] (further on: Dziennik), deposited in the AMK, kept by a Polish participant in the expedition - most likely, Stanisław Buratyński. ${ }^{10}$ No publications known to the author have referenced this immensely interesting source text, which undoubtedly deserves attention as the only document to present the course of the research expeditions on Podhale organised by the IDO. Importantly, the Dziennik was kept in accordance with the archaeological practice at the time, which involved registering the performed tasks systematically, on a daily basis. Apart from some professional notes, the publication also contains additional information, e.g. about the relations between the Polish archaeologists and the German supervisors, as well as the Nazi official's inspections on the hill and their ways of spending free time. Several fragments of the Dziennik describe mountain trips made on weekends by the Polish researchers. Additionally, the author added his own comments and digressions to the registered events, which seem to be particularly interesting from an ethnological perspective because of their personal character. The comments and digressions outline the subjective viewpoint of the presented reality and, at the same time, constitute a form of self-presentation: a presentation of both the author himself and of the entire Polish group, on behalf of which the author makes a statement. Through these individual, unofficial comments, the author uncovers the undisclosed aspects of the work in the German institutions. ${ }^{11}$ Apart from the Dziennik, the museum in Kraków also contains sketches, notes and numerous photographs (around 450) documenting the excavations in Szaflary and the participating researchers. An interesting supplement to the abovementioned archives is a commemorative sketch donated to the AMK in 2004 by Anna Kowalska-Lewicka $(2004)^{12}$ - Polish ethnologist, who, as a young member of the staff of the Landes Museum (i.e. the pre-war Prehistory Museum of the Polish Academy of Learning in Kraków), also participated in the research on the castle hill in Szaflary.

10 Dziennik prac wykopaliskowych $w$ Szaflarach, Archives of the AMK, pp. 197. The Dziennik does not state the name of the person making the notes. According to an employee of the Archives of the AMK, Doctor Marzena Woźny, the handwriting indicates that the notes were made by Buratyński, MA.

11 The Dziennik considerably supplements and enlivens the collection of archaeological findings obtained during the excavations in 1942, stored in the AMK.

12 A. Kowalska-Lewicka, Muzeum Archeologiczne PAU - czas okupacji (luźne wspomnienia) [Archaeological Museum of the Polish Academy of Learning - the Times of the Occupation (Unsystematised Recollections)]. Typescript, pp. 39. Archives of the Archaeological Museum in Kraków. 


\section{Excavation work on the Skatka Hill}

Immediately after the end of the excavation work on the castle hill, Wstepny raport $z$ prac wykopaliskowych na wzgórzu zamkowym w Szaflarach [Preliminary Report from the Excavation Work on the Castle Hill in Szaflary] was published in a German journal "Deutsche Forschung im Osten" - a press body of the IDO (John 1943: 47-53). The author of the report was introduced as Cand. Phil. Marie-Luise John, who had supervised the fieldwork on behalf of the IDO. No detailed information about her has been found in either the documentation of the SRV, or in the previous publications concerning the IDO. Kozłowski's publication (2012: 32) contains only the note that Fräulein Dufke was a member of a "small, two-person team" under Werner Radig. John's personal questionnaire was found in the Bundesarchive ${ }^{13}$ and provides more details. According to the questionnaire, the supervision of the archaeological work in Szaflary was given to a young person with no research experience. John was 23 years old when the research in Szaflary started. She did not hold a scientific title and attended classes in history studies at the time. Despite the fact that her scientific skills were, for obvious reasons, unimpressive, she had already displayed considerable experience in the national service. The personal questionnaire indicated that, in 1933, she had joined the Bund Deutscher Mädel (BDM, English: League of German Girls), a girls' section of the Nazi youth organization Hitlerjugend, and became a member of the Nationalsozialistische Deutsche Arbeiterpartei (NSDAP, English: National Socialist German Workers' Party) on 1 September 1937.

The work on the castle hill in Szaflary began on 1 July 1942. According to John, the archaeological research on the castle hill was especially advocated by Hans Malsfey, who at the time was the governor (Kreishauptmann) of Nowotarski District. ${ }^{14}$ In the author's opinion, he had "a great intuition with regard to the subject of the prehistory and the history of the Middle Ages" (John 1943: 47). Apparently, the excavation work was initiated in connection with the anthropological and ethnic research initiative being carried out at the time in Szaflary by the SRV, becoming a part of an extensive research programme on the local populations. This is indicated by a meeting between the archaeologists working on the castle hill with the members of the SRV staff, as well as a note titled Excavations and

13 Bundesarchive: R 52 IV/68. Queries were performed as part of a grant from the National Science Centre Górale Podhalańscy w nazistowskich koncepcjach narodowościowych i etnopolityce $w$ świetle dokumentacji Sektion Rassen- und Volkstumsforschung Institut für Deutsche Ostarbeit [Podhale Highlanders in the Nazi Nationalistic Concepts and Ethnopolicy in Light of the Documentation of the Section on Race and Ethnicity Research of the Institute for German Work in the East). NSC Grant, UMO-2013/09/B/HS3/03574.

${ }_{14}$ In the Polish publications, Hans Malsfey is presented as an ardent supporter of Hitler and as an NSDAP activist closely cooperating with the Gestapo (Kasperek 1990: 48). 
Ethnic Research in Nowotarski District. Castle Hill and the Population of Szaflary ${ }^{15}$ included in the "Krakauer Zeitung" on 8 July 1942. The note emphasised the complementary nature of the archaeological research with regard to cultural and racial research. According to John's report (1942: 47), the archaeological work was performed chiefly by the Sektion Vorgeschichte of the IDO and by its Director, Professor Radig ${ }^{16}$, who, at the same time, was the Chief Scientist of the Ost-Institut, as well as being the Scientific Adviser of the Governor General (Kozłowski 2012: 26, 27). Among the researchers delegated to the work in Szaflary were also the Polish archaeologists employed by the Landes Museum, i.e. the pre-war Prehistory Museum of the Polish Academy of Learning in Kraków. During the occupation, the abovementioned facility was under the authority of the Abteilung - Wissenschaft und Unterricht under the General Government (The Faculty of Education) and it was supervised by Karl A. Nowotny, an ethnologist from Vienna who was employed in the abovementioned faculty (Kozłowski 2012: 172). It should be added that John's list of the project participants does not mention the names of the Polish researchers. She only mentions that the project was carried out by "three non-German archaeologists" (John 1943: 50).

Due to its structure and content, the report prepared by John can be regarded as part of the convention of politically involved texts created by the ardent followers of Hitler for the purposes of the state's policy (Gingrich 2007: 149-151). Therefore, the author provides extensive information about the course of the excavation work and, at the same time, interprets the obtained archaeological materials in the spirit of national socialist principles. Even in the introduction of the report, she already indicates the accuracy of the formulated theses and suggests that the assumed research goals have been achieved. She writes, therefore, that even before the work began, a preliminary inspection of the remains of the walls on the hills had shown that they matched the "East German castles erected there during the colonisation period in the Middle Ages". Continuing her argument, she states that the "existence of the castle in the East German style in the foreland of the Tatra Mountains constitutes the best proof for the presence of German settlements in Podhale even in the Middle Ages", and that this proves the thesis about the resettlement of the "East by Germans after absorbing the Slavs between the 6th and the 12th century" (sic!) (John 1943: 47). Further on, the research is described in the report. The author begins by providing basic information about Szaflary and an overview of the area subjected to the archaeological penetration. She also at-

15 Ausgrabung und Volksforschung im. Kr. Neumarkt. Burgberg und Bevölkerung von Szaflary [Excavations and Ethnic Research in Nowotarski District. Castle Hill and the Population of Szaflary], Rg Neumarkt, 6. Juni Typescript, p. 2. Archives of the Archaeological Museum in Kraków. File on the Szaflary site, Nowy Targ District.

16 Radig, after obtaining a $\mathrm{PhD}$ in archaeology in 1933, worked for the Higher School of Pedagogy in Elbląg. He came to Kraków in 1940 and was quickly promoted to the rank of Professor (Herr Profesor), thus becoming a key member of the IDO (Kozłowski 2012: 26-27). 
tempts to analyse the results of the research. John's preliminary evaluation and interpretation of the material is very superficial and general. However, this does not prevent the author from formulating a final conclusion that the findings from the excavations supported by the historical sources prove the existence of a castle, "the purpose of which was to protect the population of the Tatra Mountains during the German colonisation in the East" (John 1943: 53). In unconditionally assuming the Nazi point of view, she ignores the Polish sources and historical studies which, in fact, did not reject the German participation in the settling of Podhale. ${ }^{17}$

The version of the excavation work on the hills presented by John is, in a considerable manner, verified and nuanced by the Dziennik prac wykopaliskowych, which was mentioned earlier. The Dziennik provides notes containing meticulous and regular basic research data, such as the weather conditions, the number of staff (archaeologists and support workers), dig sites, findings, systematically prepared sketches, drawings and plans, and other interesting data and events. Thus, the very first pages of the notebook contain detailed notes about the group of Polish researchers. An entry from 29 June states that on Doctor Nowotny's request, "excavation research in the area [... illegible] of the castle in Szaflary is to be carried out". The research staff was to include Doctor Stefan Nosek and Buratyński, MA under the supervision of Doctor Jamka (Dziennik, 3). According to a note in the Dziennik, the abovementioned staff departed from Kraków on 29 June. On the same day, the Polish researchers met with the District Governor Malsfey in Nowy Targ, where they received food stamps. On the next day, the archaeologists visited a clergy house in Szaflary "in order to introduce themselves to the parish priest and become acquainted with the anthropological expedition that had been ongoing in Szaflary for two weeks" (Dziennik, 9). The Polish researchers were also given 12 young highlanders from the construction service (Baudienst) in Poronin to help with the earthwork. Together with the archaeologists from Kraków, they formed the core team who worked continuously for almost three months, until 26 September (Dziennik, 194). At times, however, the staff was considerably reduced. For instance, on 7 September, there were only "seven workers" in the field. As the author of the Dziennik noted, "three highlanders have scabies, one has gastritis and one is on a leave" (Dziennik, 176). At the same time, "new scientific forces" from the Landes Museum in Kraków joined the team of archaeologists. For instance, Anna Kowalska, a well-known post-war ethnologist associated with the Polish Academy of Sciences, who on Doctor Nowotny's permission "was to take part in the excavation research", arrived in Szaflary on 11 July together with Doctor Jamka (Dziennik, 48-49; Kowalska-Lewicka 2004: 30-31). Another temporary participant in the research was Miss Trzepaczówna, later known as the archaeologist Maria Cabalska, who was associated with the Museum in Kraków. In the con-

${ }^{17}$ According to Polish historians, in the Middle Ages, both Polish settlers from Małopolska and German colonials from the neighbouring Spiš and Saxony, brought by the Polish magnate families, came to Podhale (Adamczyk 1993). 
text of the deliberations on Polish-German relations, the comments of the author of the Dziennik concerning John are worth noting. An entry from 7 July states that, "Ms John from the Ost-Institut in Kraków was assigned to the work and arrived at the excavation site" (Dziennik, 37). According to the notes made in the Dziennik, John often went to Kraków, and during a stay in Szaflary, her presence at the excavation site came down to visits lasting just a few hours. For instance, on 17 July, the author of the Dziennik noted: "Ms John returned from Kraków and stayed at the excavation site between 10 and 12 a.m. and again between 5 and 5:30 p.m." (Dziennik, 74). However, she left to go to Kraków on 22 July. She returned to Szaflary after two days, only to leave the site again on 27 July. The schedule of John's stay in Szaflary in August and September looks similar (Dziennik, 182-191). According to the notes, the Polish archaeologists treated the German "Director" with reserve. In their eyes, she did not have the sufficient competences, as is shown by the following note: "Buratyński started to draw parts of the wall enclosing Dig Site II, which Ms John had drawn unsuccessfully three times already" (Dziennik, 48-49). A. Kowalska-Lewicka also wrote about the young manager in a sneering manner: "A car with Germans in uniforms accompanied by Frauhlein Piohn (sic!) appeared every now and then (sic!). Her distinguishing features were a monocle she wore, she always stood with her legs apart, just like the Gestapo officers, and with the demeanour of an expert she stated that the caverns were typical Germanic ones" (Kowalska-Lewicka 2004: 31).

Apart from the digression aimed at John, the author of the Dziennik also made a suggestive note concerning the participation of the representatives of the Sektion Vorgeschichte of the IDO and the staff from the Landes Museum in the excavations. A fragment of the German newspaper "Krakauer Zeitung" from 8 July concerning the archaeological work in Szaflary was glued to an entry from 12 July 1942. Next to the press article, the author included a correction note explaining that the note "contains a mistake, because the research is being conducted by the State Museum (Landes Museum), rather than the IDO". He added that, on the authority of the latter, "Ms John is cooperating with the Polish researchers" (Dziennik, 56). As can be seen, the author of the Dziennik was not indifferent to the omission of the Polish team's real contribution to the conducted work. This comment correcting the press note manifests the scientific ambition of the Polish researchers and a need to note the leading role that the Landes Museum was playing in the entire undertaking, at least in the Dziennik. However, upon a closer look at the structure of the employment and the payroll in the IDO, as well as the recollections of the Polish researchers written down after the war, Buratyński's correction note takes on another meaning. Doctor Jamka, an archaeologist from Kraków who led the Polish group on the authority of the Landes Museum, was employed in the Sektion Vorgeschichte of the IDO for at least a year, i.e. between April 1942 and April 1943. He received an admittedly small, yet regular remuneration (Kozłowski 2012: 33-34). Therefore, he represented both insti- 
tutions, although he identified himself more closely with the Museum. What is more, as Kozłowski pointed out, despite the aversion to Radig demonstrated in his post-war memoirs ${ }^{18}$, Doctor Jamka carried out the orders of his German boss more or less diligently during the occupation. He carried out research and conservation work, translated Polish articles, wrote texts for Radig and supervised the work of the Polish archaeologists in the Landes Museum. It should be added that, at the same time, Jamka conducted clandestine classes for Polish students at the same institution. When trying to better understand the Polish-German relations outlined above, it should be taken into consideration that, in the case of the institutions being discussed here, an unusual situation occurred. Both Radig and Nowotny, even though Berlin had officially prohibited the Germans from contacting the Polish academics, were not strictly prejudiced against the Polish researchers (Kozłowski 2012: 75-77). They did not, in principle, discredit the competence and knowledge of the Poles, contrary to other German researchers; for instance, Doctor Erhard Riemann (Head of the SRV from 1943) did not accept a "compilation of the results of the Polish research due to political and scientific reasons" (1943). ${ }^{19}$ It should also be noted that Doctor Nowotny was presented in a more positive light in post-war evaluations by the Polish archaeologists. His relations from the occupation period mention him as a person who was friendly and kind to the Poles, and who not only supported his subordinates, but also protected them from German inspections and repressions (Jamka 1964: 2012-215; Kowalska-Lewicka 2004:3-4). On the other hand, some people would speak about Radig with reserve, emphasising his anti-Polish attitude (Jamka 1964: 215). This probably resulted from the fact that as an ardent Nazi, he cooperated closely with the GG and had a leading role in the IDO structures as the chief Leiter. The distant attitude could also have resulted from Radig's unhindered appropriation of the Poles' scientific achievements (inter alia, the works of Doctor Jamka) (Kozłowski 2012: 45). The abovementioned situations illustrate both the practices used in the Nazi institutions and the relations between the dominant Germans and their subordinate Polish academics. In the Nazi government departments operating within the General Goverment, including the Ost-Institut, all supervisory functions were held by German scientists. On the other hand, the Poles were employed as Wissenschaftliche Hilfskräfte - "assistant scientific workers", referred to as as

18 In his memoirs from 1964, Jamka briefly described Radig's research and organisational activity in the GG as the Head of the Anthropological Section of the Ost-Institut and noted that Radig "was known for his anti-Polish attitude". He also pointed out to his German employer that he did not want to return the archaeological findings to the museum after the exhibition entitled Germanenerbe im Weichslraum, the aim of which was to confirm the Germanic character of the Polish lands, was closed (Jamka 1964).

19 Arbeitsbericht der Sektion Rassen- und Volkstumsdforschung, Kraków, 7.7.1943. E. Riemann, typescript, Archives of the Jagiellonian University, IDO SRV, Box. 01/01/09. 
is confirmed by the payroll of the IDO. ${ }^{20}$ As low-ranking personnel, the Polish academics were assigned to various tasks, often performing key tasks. ${ }^{21}$ They carried out research, translated Polish texts into German, provided the German supervisors with consultations, and prepared materials for publication. However, the official documents and the German publications omit their names. The tasks performed by these individuals were instead signed with the names of German officials (Kozłowski 2012: 77; Maj, Trebunia-Staszel 2015). The presented deliberations also suggest that, in the case of the Polish researchers working for the IDO, we should go beyond the simplified evaluation categories, i.e. either a sinful collaboration or patriotic service sabotaging the works of the IDO (BałukUlewiczowa 2004), and replace these with a broader spectrum of factors and circumstances. First and foremost, I am talking here about everyday existence under the occupation and the perspectives of a regular person who, in the absurd time of a war, enslavement and a regime tries, in spite of everything, to live with dignity, at the same time avoiding acts of betrayal, informing, looting and violence. Undoubtedly, the fact that they participated in the work of the IDO was a shameful episode for the Polish researchers; but nevertheless, it was not only these scientists who worked in state institutions. According to Kozłowski, among those who worked "for the Germans" in occupied Poland were Polish teachers, policemen, bank officials, doctors, municipal service workers, physical workers and lowerranked officials. Only their topmost superiors were German (Kozłowski 2012: 33). It is not my aim to defend the Polish academics who worked in the IDO, but only to draw attention to the ambiguous situations and matters that may affect a person, as well as his or her life, everyday existence and often difficult choices. To end this matter, I would also like to point out that the Poles had different attitudes towards the IDO. Some undertook work there, seeing in it a chance for a permanent, even if low, income and relative safety. It should also be stressed that many Polish researchers simultaneously carried out underground activities while working in the Ost-Institut. Thanks to their employment in the IDO, they had access to academic resources, which in turn gave them an opportunity to hide and protect Polish cultural property (Bałuk-Ulewiczowa 2004; Kozłowski 2012; Kowalska-Lewicka 2004). However, there were also researchers who decided to work in the IDO in order to develop their own professional career (Mękarska-Kozłowska 2000: 111). Furthermore, there were cases in which Polish academics, despite strong insistence and entreaties from the German officials, vehemently refused to cooperate (Michalewicz 2005: 497, 777, 885).

20 Personalaufstellung der Sektion Rassen-und Volkstumsforschung am Institut für Deutsche Ostarbeit in Krakau, Archives of the Jagiellonian University, "Old IDO” Box. 71. See also (Bałuk-Ulewiczowa 2004).

${ }^{21}$ During the research conducted by the SRV in Szaflary, it was the Poles who performed most of the fieldwork related to the Nazi project (Bałuk-Ulewiczowa 2004: 91-93; Maj, Trebunia-Staszel 2015). 


\section{Prestige, renown and the fiasco of the research}

In light of the available data not only the researchers themselves and the academic institutions were engaged in the archaeological work on the castle hill, but also the representatives of the German apparatus of power. Due to the mediaeval origins of the castle ruins, the excavations in Szaflary grew to almost exemplary proportions, becoming a showpiece of the German research undertakings in Podhale. For the Nazi officials, it was an important undertaking, for both academic and propaganda reasons. The research was intended to confirm the role of the German involvement in settling Podhale and, as a consequence, to justify the right of the Reich to the occupied territories. The importance and prestige of the archaeological work may be signified by the numerous inspections and visits to the hill. As was noted by the author of the Dziennik, the archaeologists working on the Skałka Hill were visited by the heads of the institutes carrying out the research: Radig from the Sektion Vorgeschichte of the IDO, Nowotny from the Landes Museum, and Ingeborg Sydow from the Sektion Rassen-und Volkstumsforschung, who was conducting ethnological work in Szaflary at the same time. On 6 August, Wilhelm Cobliz, Director of the entire Ost-Institut, appeared at the site accompanied by two Germans [a note by STS]. Additionally, the site was often visited by District Governor Malsfey (Dziennik, 126, 194-95), who treated the project as a personal challenge, following the progress of the work and ensuring an efficient path. Apart from the abovementioned persons, the hill was also visited by some observers not connected with academic institutions; for instance, the local parish priest, assistant curate, District Governor Malsfey's wife and the chief of the labour camps in the Nowotarski District along with his wife. This leads to the conclusion that the excavations on the hill enjoyed some popularity and were considered as a curiosity and an attraction.

According to the notes in the Dziennik, the work on the hill finished on 16 September; however, two days later, the excavation site was visited by a special commission that included "Professor Radig, District Governor Malsfey, Doctor Troschke and two other Germans". This commission announced:

the round building, which is referred to as a tower, cannot be re-covered with earth, as it constitutes an example and model of a German mediaeval construction; thus, it will remain uncovered and will be appropriately reinforced and secured against the weather conditions. Therefore, the earth which had already been $3 / 4$ filled in had to be removed (Dziennik, 194-195).

This concerned the aforementioned supposed "Jamka's embarrassing mistake", which caused him to fear a reprisal from Radig (Kozłowski 2012: 16). The information found in the Dziennik verifies the above assumption, indicating that it was the German commission that decided to further investigate the alleged rotunda. Kowalska commented on the incident in her draft as follows: "On the top of the hill, we found a 'typically Germanic' keep, round with thick stone walls. 
The Germans went mad with delight, and we drew each stone diligently - but unfortunately, further excavations revealed that it was a 19th-century kiln used for burning lime (Kowalska-Lewicka 2004: 31). Following a decision of the commission, the excavation work on the hill was not closed until 25 September. On that day, the staff finished packing the archaeological materials into boxes, and the young highlanders closed down their quarters. The last entry in the Dziennik comes from 26 September and it ends with the information that "Doctor Jamka, Doctor Nosek and Buratyński returned to Kraków for good” (Dziennik, 197).

\section{Science - pseudoscience}

The case of the archaeological research in Szaflary offers an accumulation of complex stories and intricacies concerning the work conducted under the aegis of the Nazi research institutions. They reveal a complex network of connections and relations, and of official and undisclosed actions, as well as the non-obvious status of the produced data and raise questions about many widely-held and simplified opinions. This refers, first and foremost, to the tendency to discuss the German research as belonging to the category of a pseudoscientific absurdity, as well as negating contemporary studies on the documentation of the IDO due to the fact that they were a part of the heinous policy of the Third Reich (Schafft 2004). Undoubtedly, the research conducted by the SRV was submitted to the ethnic policies of the Third Reich. The research was a part of the Nazi programme of enslavement, domination and extermination of the populations in the occupied territories and, in this sense, it was unethical (Schafft 2004; Libera 2015; Maj, Trebunia-Staszel 2015). At the same time, we cannot ignore the fact that the scientists employed in the SRV used research methods and tools developed at academies and universities. A good example of these complex relations between science and politics is seen in the archaeological research discussed in the text. As has been shown, the aim of the excavations in Szaflary was determined by the ethnic policies of the occupying force towards Podhale, and the entire undertaking, despite being a fiasco, was interpreted as a scientific achievement that confirmed the Nazi thesis about the German origins of the construction (John 1943). At the same time, the excavations themselves were carried out diligently, according to the set of archaeological research procedures available at the time. After the war, the materials collected during the excavations became a basis for a comparative analysis by the archaeologist from Kraków Alicja Wałowy, and led to a conclusion that confirmed the mediaeval origins of the construction from the first phase of the settlement of Podhale, i.e. from the 13th and the 14th centuries ${ }^{22}$ (Wałowy 1960). A statement

22 It is worth adding that the exact date and circumstances that led to the building of the structures have not been determined yet. A difficulty arises from the fact that the majority of the 
from a Polish physical anthropologist, Professor Krzysztof Kaczanowski, is worth mentioning here. After familiarising himself with the documentation from the archaeological research of the SRV, he emphasised that, in terms of the methodology, the collected data (anthropometric measurements) was viable and had a "full scientific value and as such, can and should be analysed". ${ }^{23} \mathrm{He}$ stressed that the value of the collected research material should be distinguished from its ideological, racist interpretation, which had nothing to do with science (Kaczanowski 2015: 80). On the other hand, Zbigniew Libera observed that it is impossible to completely separate the wheat from the chaff (Libera 2015: 26). The Nazi ideology was integrated with the research theory and practice. It constituted a significant factor in stimulating and explaining the research conducted on the occupied territories. Nevertheless, no separate knowledge discipline, and no new "national socialist ethnology" or anthropology was created by the Reich. As was indicated by Ute Michel, the fact that the anthropologists working in the SRV assumed a causeand-effect relationship between race and culture, and in this way constructed theses about the historical continuity of German influences was, unfortunately, a characteristic premise not limited to national socialism. Conducting research at the state's request was a well-known practice, and one that was applied in many European countries even before World War II (Michel 2000: 164). Therefore, in applying the label of pseudo-scientific to the nature to the research conducted by the IDO we, in a sense, are absolving the academics from their responsibility for intentionally using the authority of the science and knowledge they obtained in academies for dishonourable and heinous purposes. In the present discussion on the usefulness of the anthropological knowledge of the Third Reich ${ }^{24}$, it should

documents concerning that period, which constituted an extensive archive of the District Governor, were destroyed during a fire that occurred in Nowy Targ in 1784 (Adamczyk 1993: 26-27).

23 The collection of ethnographic, sociological, medical and anthropological data left by the group of researchers of the SRV carries a similar ambiguity. Today, the collection from Podhale, comprising over 22 thousand archival pieces, is valuable material for studies on the history and broadly-defined culture of the region and, at the same time, contributes to the research on the involvement of science in regimes, as well as on the issue of responsibility and ethics in research.

24 As suggested by the German researcher, Patrik Wagner, when discussing the usefulness of science for carrying out the policy of the Third Reich, it is also worth considering what is the real correlation between scientific expertise and the specific actions of the Nazi authorities. Undoubtedly, in their anthropological texts and analyses, the researchers presented to their Nazi patrons the possibilities of carrying out their radical goals. They also provided them with data that was used to make selections, banish populations and commit murders. On the other hand, Hitler and his officials knew, without scientific explanations, that all European Jews should be murdered and the Slavonic nations banished. Many Hitlerian decision-makers did not value science too greatly. This is greatly signified by the fragment of a German newspaper mentioned by Wagner: "What the state is, we know from Führer, we do not care what others write about this topic. Führer does not need any professors to carry out his visions" (2012: 114-115). The abovementioned problem is also discussed by Dan Stone in the text The Real Role of the Anthropologists (2005), which includes a review of Schafft's book From Racism to Genocide. 
be remembered that using science as a tool for reinforcing dominance was not only an affliction of the Nazi researchers (Kowalski 2015: 42). The problem of the involvement of anthropology in a regime, or an oppressive system of power, has accompanied our discipline from the beginning of its existence (Gough 1968; Traverso 2011: 76-89) and it still constitutes a great challenge for anthropologists. For this reason, there is a need to continuously remind ourselves and reflect on these dangerous relations.

\section{Archival Materials}

\section{Archives of the Archaeological Museum in Kraków (A AMK)}

Dziennik prac wykopaliskowych w Szaflarach [Journal of the Excavation Work in Szaflary]. Notebook A5 format, pp. 197. Catalogue of sites. File of the Szaflary site, Nowy Targ District. Documentation of the research conducted in 1942 supervised by Rudolf Jamka.

Anna Kowalska-Lewicka, Muzeum Archeologiczne PAU - czas okupacji (luźne wspomnienia) [Archaeological Museum of the Polish Academy of Learning - the Times of the Occupation (Unsystematised Recollections)], 2004. Typescript, pp. 39.

Archives of the Jagiellonian University (A JU)

Arbeitsbericht der Sektion Rassen- und Volkstumsforschung, Kraków, 7.7.1943. Signed

E. Riemann. Typescript. Collection of the Sektion Rassen- und Volkstumsforschung, Institut für Deutsche Ostarbeit, provided by National Anthropological Archives Smithsonian Institution. Box. 01/01/09.

Personalaufstellung der Sektion Rassen- und Volkstumsforschung am Institut für Deutsche Ostarbeit in Krakau, "Old IDO", Box.71.

Bundesarchive in Berlin (previously the Berlin Document Centre).

Institut für Deutsche Ostarbeit R 52 IV/1-152.

\section{Internet sources}

Dan Stone, Review of Schafft, Gretchen E., From Racism to Genocide: Anthropology in the Third Reich. H-Genocide, H_Net Review. March 2005, http://www.h-net.org/reviews/ showrev.php?id=10280 (access: 28.05 .2014$)$.

\section{Bibliography}

Adamczyk M.

1993 Rys historyczny Szaflar. Okres staropolski [Outline of the History of Szaflary. The Old Polish Period], in: M. Adamczyk (ed.), Szaflary. Wieś podhalańska [Szaflary. A Podhale Village], Nowy Targ, p. 13-32. 
Bałuk-Ulewiczowa T.

2004 Wyzwolić się z błędnego koła. Institut für Deutsche Ostarbeit w świetle dokumentów Armii Krajowej i materiałów zachowanych $w$ Polsce [Ending the Vicious Circle. The Institute for German Work in the East in Light of the Documents of the Home Army and the Materials Preserved in Poland], Kraków.

Cabalska M.

1991 Pradzieje Nowego Targu i okolicy [Prehistory of Nowy Targ and its Vicinity], in: M. Adamczyk (ed.), Dzieje Miasta Nowego Targu [History of the Town of Nowy Targ], Nowy Targ, p. 27-29.

Chwalba A.

2003 Historię trzeba pisać od nowa [History Should be Written All Over Again], "Tygodnik Powszechny", no. 34 (2824), p. 4.

Engelking B., Grabowski J. (eds.)

2018 Dalej jest noc. Losy Żydów w wybranych powiatach okupowanej Polski [From Now On, it Will Be the Night. The Fate of the Jews in Selected Districts of Occupied Poland], Warszawa.

Fliethmann E.

1942 Bericht $\ddot{b} b e r$ anthropologisch-ethnologische Untersuchungen in Szaflary und Witów, zwei Góralenorten im Kreise Neumarkt, "Deutsche Forschung im Osten”, no. 2(7), p. 272-274.

Gąsiorowski T.

2010 Podhale w planach niemieckiego okupanta [Podhale Region within Germans Occupation Plan] "Biuletyn IPN", no. 1-2 (108-109), p. 20-23.

Gingrich A.

2007 Niemiecka antropologia w okresie Trzeciej Rzeszy [German Anthropology during the Nazi Period], in: F. Barth, A. Gingrich, R. Parkin, S. Silverman (eds.), Antropologia. Jedna dyscyplina czety tradycje: brytyjska, niemiecka, francuska i amerykańska [One Discipline, Four Ways: British, German, French and American Anthropology], transl. J. Tegnerowicz, Kraków, p. 129-157.

Gough K.

1968 Anthropology and Imperialism, "Monthly Review"19, p. 12-27. Jamka R.

1964 Urywki z okupacyjnych wspomnień archeologa [Fragments from the Occupation Memories of an Archaeologist], in: M. Zaręba, A. Zaręba (eds.), Alma Mater w podziemiu [Alma Mater in the Underground], Kraków, p. 208-221.

John M.L.

1943 Vorbericht über die Ausgrabung auf dem Burgberg von Szaflary, "Deutsche Forschung im Osten", no. 3(1/2), p. 47-53.

Kaczanowski K.

2015 Ocena badań antropologicznych, medycznych i psychologicznych prowadzonych na Podhalau, Łemkowszczyźnie i innych terenach Polski przez IDO [Evaluation of the Anthropological, Medical and Psychological Research in Podhale, Łemkowszczyzna and other Territories of Poland Conducted by the Institute for German Work in the East], in: M. Maj (ed.), Antropologia i etnologia w czasie wojny. Działalność Sektion Rassen- und Volkstumsforschung Institut für Deutsche Ostarbeit, Krakau 1940-1944, w świetle nowych materiałów źródłowych [Anthropology and Ethnology in the Times of War. The Activity of the Section on Race and Ethnicity Research of the Institute for German Work in the East, Kraków 1940-1944, in Light of New Source Materials], Kraków, p. 75-94. 
Kamiński J.

1993 Moja rodzinna wieś Szaflary [My Home Village Szaflary], in: M. Adamczyk (ed.), Szaflary. Wieś podhalańska [Szaflary. A Podhale Village], Nowy Targ, p. 159-170.

Kasperek J.

1990 Podhale $w$ latach wojny i okupacji niemieckiej 1939-1945 [Podhale during the War and the German Occupation between 1939 and 1945], Warszawa.

Kowalski M.W.

2015 Antropolodzy na wojnie. O brudnej użyteczności nauk społecznych [Anthropologists during the War. About the Dirty Use of Social Sciences], Warszawa.

Kozłowski S.K.

2012 Archeologiczne królestwo Wernera Radiga w Generalnym Gubernatorstwie [Archaeological Kingdom of Werner Radig in the General Government], Kraków.

Libera Z.

2015 Antropologia biologiczno-kulturowa i polityka rasowa III Rzeszy $w$ działalności Sektion Rassen- und Volkstumsforschung Institut für Deutsche Ostarbeit [Biological and Cultural Anthropology and Racial Policy of the Third Reich in the Activity of the Section on Race and Ethnicity Research of the Institute for German Work in the East], in: M. Maj (ed.), Antropologia i etnologia w czasie wojny. Działalność Sektion Rassen- und Volkstumsforschung Institut für Deutsche Ostarbeit, Krakau 1940-1944, w świetle nowych materiałów źódłowych [Anthropology and Ethnology in the Times of War. The Activity of the Section on Race and Ethnicity Research of the Institute for German Work in the East, Kraków 1940-1944, in Light of New Source Materials], Kraków, p. $25-74$.

Maj M., Trebunia-Staszel S.

2015 Działalność Referatu Etnologii Sekcji Rasowo-Ludoznawczej w świetle nowych materiatów źródłowych [The Activity of the Ethnology Office of the Section on Race and Ethnicity Research of the Institute for German Work in the East in Light of New Source Materials], in: M. Maj (ed.), Antropologia i etnologia w czasie wojny. Działalność Sektion Rassen- und Volkstumsforschung Institut für Deutsche Ostarbeit, Krakau 1940-1944, w świetle nowych materiałów źródłowych [Anthropology and Ethnology in the Times of War. The Activity of the Section on Race and Ethnicity Research of the Institute for German Work in the East, Kraków 1940-1944, in Light of New Source Materials], Kraków, p. 103-144.

Maj M., (ed.)

2015 Antropologia i etnologia w czasie wojny. Działalność Sektion Rassen- und Volkstumsforschung Institut für Deutsche Ostarbeit, Krakau 1940-1944, w świetle nowych materiałów źródłowych [Anthropology and Ethnology in the Times of War. The Activity of the Section on Race and Ethnicity Research of the Institute for German Work in the East, Kraków 1940-1944, in Light of New Source Materials], Kraków.

Majda J.

1979 Góralszczyzna w twórczości Stanisława Witkiewicza [Highlander Culture in the Works of Stanisław Witkiewicz], Wrocław, p. 114-115.

Mękarska-Kozłowska B.

2000 Burza nad Lwowem [Storm over Lviv], Lublin.

2000 Mozaika wspomnień, Lublin.

Michalewicz J.

2005 Relacje pracowników Uniwersytetu Jagiellońskiego o ich losach osobistych i dziejach uczelni w czasie drugiej wojny światowej [Accounts of the Staff of the Jagiellonian 
University about their Fate and the History of the University during World War II]. From Works in the Archives of the Jagiellonian University, series F., vol. 5, Kraków. Michel U.

2000 Ethnolpolitische Reorganisationsforschung am Institut für Deutsche Ostarbeit in Krakau 1941-1945, in: B. Streck (ed.), Ethnolohie und Natibalsozialismus, Gehren, p. 149-166.

Plügel A.

1941a Das Rassenbild des Vorfeldes im deutschen Osten, "Das Vorfeld” Schulungsblätter für den Nationalsozialisten im Generalgouvernement, 2 Jahr., F. 6, 6-15.

1941b Die podhalanischen Góralen im südlichsten Teil des Kreises Neumarkt. I Teil, "Die Burg” Vierteljahresschrift des Instituts für Deutsche Ostarbeit Krakau, no. 2(3), p. $54-66$.

Rybicka A.

2002 Instytut Niemieckiej Pracy Wschodniej. Institut für Deutsche Ostarbeit 1940-1945 [Institute for German Work in the East. Institut für Deutsche Ostarbeit 1940-1945], Warszawa.

Schafft G.

2004 From Racism to Genocide. Anthropology in the Third Reich, Illinois.

Słuszkiewicz B.

1993 Rys historyczny Szaflar. Okres międzywojenny [Outline of the History of Szaflary. The Interwar Period], in: M. Adamczyk (ed.), Szaflary. Wieś podhalańska [Szaflary. A Podhale Village], p. 81-110.

Szatkowski W.

2012 Goralenvolk. Historia zdrady [Goralenvolk. A History of Betrayal], Kraków. Traverso E.

2011 "Wyniszczenie ras" [The "Extinction of Races"], in: E. Traverso, Europejskie korzenie przemocy nazistowskiej [The Origins of Nazi Violence], transl. A. Czarnacka, Warszawa, p. 76-89.

2014 Historia jako pole bitwy. Interpretacja przemocy $w$ XX wieku [History as a Battlefield. Interpretation of the Violence of the 20th Century], transl. S.F. Nowicki, Warszawa.

Trebunia-Staszel S.

2017 Rasa - naród - kultura [Rase - Nation - Culture], in: J. Jasionowska, K. Kaniowska (eds.), Kolokwia Antropologiczne [Anthropological Symposia], Warszawa.

Wagner P.

2012 Współtwórcy koncepcji zagłady - niemieccy uczeni a narodowosocjalistyczna polityka podbojów Europy Wschodniej [The Co-creators of the Concept of Extermination German Academics and the National Socialist Policy of Conquests in Eastern Europe], in: P. Madajczyk, P. Popieliński (eds.), Inżynieria społeczna. Między totalitarna utopia a czastkowym pragmatyzmem [Social Engineering. Between Totalitarian Utopia and Partial Pragmatism], Warszawa, p. 103-115.

Wałowy A.

1960 Materiały z badań archeologicznych na średniowiecznym zameczku w Szaflarach, pow. Nowy Targ [Materials from the Archaeological Research on the Mediaeval Castle in Szaflary, Nowy Targ District], "Materiały Archeologiczne”, no. II-22, p. 295-332.

Wnuk W.

1980 Walka podziemia na szczytach [Resistance Fight on the Tops ]. 